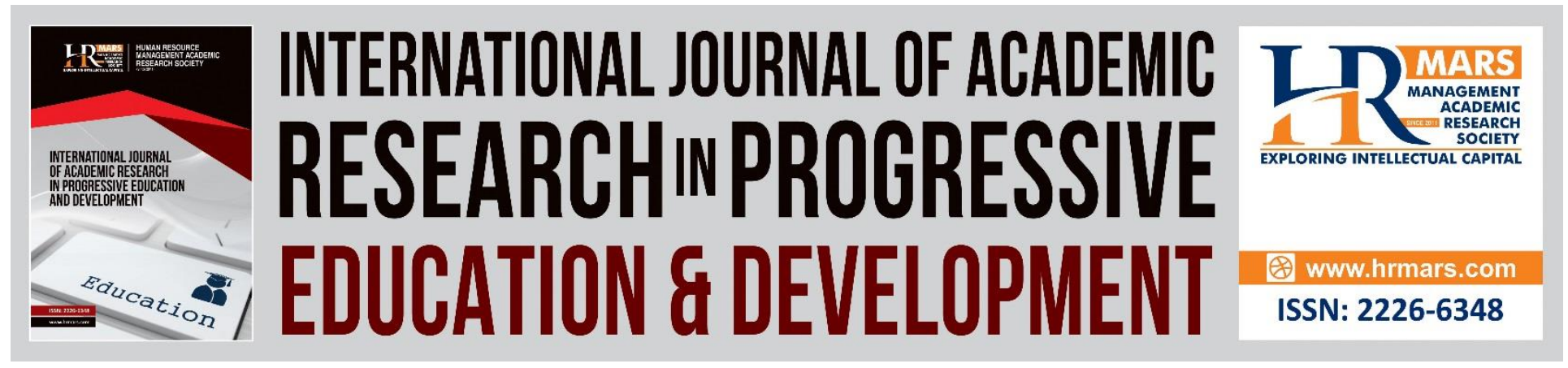

\title{
The Use of Task-Based Learning (TBL) to Improve form Four Students' Performance in Narrative Writing
}

Jamie Ashwini Pragasam, Charanjit Kaur Swaran Singh, Tarsame Singh Masa Singh, Nor Azmi Mostafa, Hasimah Ja'afar, Maria Shu Abdullah, Noraini Zulkepli \& Farah Natchiar Mohd. Khaja

To Link this Article: http://dx.doi.org/10.6007/IJARPED/v7-i2/4288

DOI: $10.6007 /$ IJARPED/v7-i2/4288

Received: 26 May 2018, Revised: 18 June 2018, Accepted: 26 June 2018

Published Online: 08 July 2018

In-Text Citation: (Pragasam et al., 2018)

To Cite this Article: Pragasam, J. A., Singh, C. K. S., Singh, T. S. M., Mostafa, N. A., Ja'afar, H., Abdullah, M. S., ... Khaja, F. N. M. (2018). The Use of Task-Based Learning (TBL) to Improve form Four Students' Performance in Narrative Writing. International Journal of Academic Research in Progressive Education and Development, $7(3), 48-59$.

\section{Copyright: (C) 2018 The Author(s)}

Published by Human Resource Management Academic Research Society (www.hrmars.com)

This article is published under the Creative Commons Attribution (CC BY 4.0) license. Anyone may reproduce, distribute, translate and create derivative works of this article (for both commercial and non-commercial purposes), subject to full attribution to the original publication and authors. The full terms of this license may be seen at: http://creativecommons.org/licences/by/4.0/legalcode

Vol. 7, No. 2, April 2018, Pg. 48 - 59

http://hrmars.com/index.php/pages/detail/IJARPED

JOURNAL HOMEPAGE

Full Terms \& Conditions of access and use can be found at http://hrmars.com/index.php/pages/detail/publication-ethics 


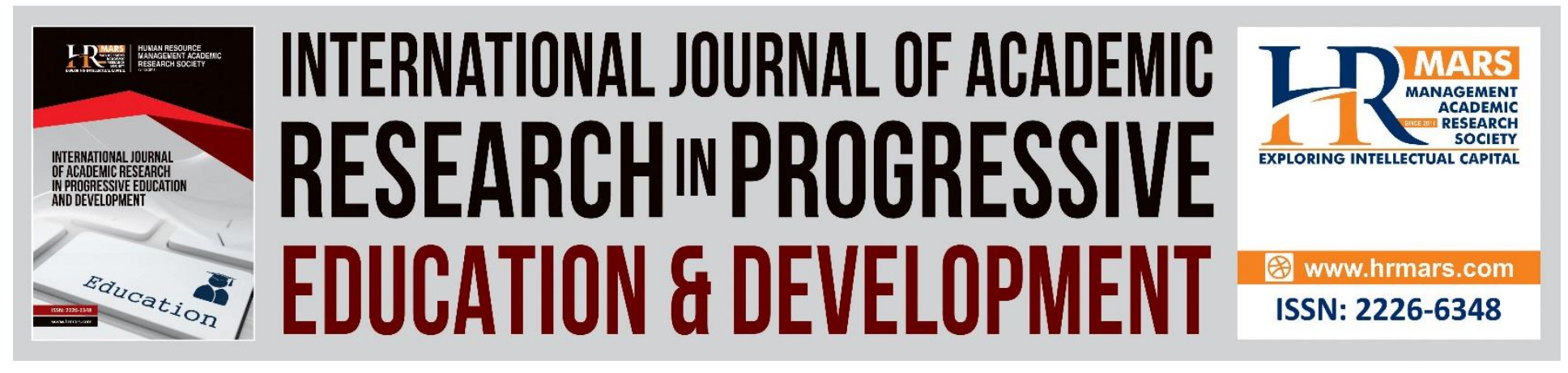

\title{
The Use of Task-Based Learning (TBL) to Improve form Four Students' Performance in Narrative Writing
}

Jamie Ashwini Pragasam¹, Charanjit Kaur Swaran Singh"1, Tarsame Singh Masa Singh², Nor Azmi Mostafa' ${ }^{1}$, Hasimah Ja'afar ${ }^{1}$, Maria Shu Abdullah'1 , Noraini Zulkepli \& Farah Natchiar Mohd. Khaja ${ }^{1}$

\author{
${ }^{1}$ Faculty of Languages and Communication, Universiti Pendidikan Sultan Idris, Malaysia \\ ${ }^{2}$ English Language Unit, Language Department, Institute of Teacher Education, Tuanku Bainun \\ Campus, Malaysia
}

\begin{abstract}
The study aims at investigating whether Task-based learning (TBL) can improve narrative writing composition among form four students. Action research was used as the research design in this study. The data were collected and analysed in a qualitative paradigm. Observation, reflective journal, semi-structured interview and documents were used to collect the data. A reflective journal with guidance was distributed among the students and was verified through an interview session for triangulation. Students' written compositions were also collected and analysed to evaluate their performance. The findings reveal that students performed well in Taskbased learning Lesson compared to other lessons. Students perceived Task-based learning as an approach that could help them in narrative writing skill and reflected positive responses. The findings of the study reveal that Task-based learning improved students' performance in narrative writing.
\end{abstract}

Keywords: Task-Based Learning, Narrative Writing, Action Research

\section{Introduction}

English has become an important language at national and international level in all fields. Scoring a good grade in the "Sijil Pelajaran Malaysia" (SPM) is an advantage for the students as it could lead to a better future for them. Despite the emphasis on the importance of mastering English language in the current Malaysia Education Blueprint and $21^{\text {st }}$ century learning, English language proficiency among rural students in Malaysia is still unsatisfactory (Wreikat, Kabilan, \& Abdullah, 2014). Scoring high grades for Paper 1 especially in Section B which is continuous writing in SPM English is an advantage for students as it carries more marks than Section A. In fact, it is a 


\section{INTERNATIONAL JOURNAL OF ACADEMIC RESEARCH IN PROGRESSIVE EDUCATION AND DEVELOPMENT}

Vol. 7, No. 2, April 2018, E-ISSN: 2226-6348 @ 2018 HRMARS

golden opportunity to score easily for the students if they choose the narrative genre of essay for their writing. In conjunction, a better approach, Task-based learning, is needed for the teachers to teach narrative writing.

This study focuses on students' performance and perception when narrative writing skill is acquired through Task-based learning. Students' ability to master narrative writing and perspectives when Task-based learning is introduced are analysed. Task- Based LTasearning approach has certain stages on its own and this study was conducted to examine how students respond and perceive every stage and element of Task-based learning. Action research is used in this study as it is targeted at improving the student's narrative writing. Therefore, the data collection and data analysis are based on the qualitative paradigm as the findings are from interpretation and understanding of the data. The following are the research questions answered by the study:

1. What are the effects of using Task-based learning on students' performance in narrative writing?

2. What are the students' perception of Task-based learning in narrative writing?

The teaching of writing in ESL has seen dramatic changes in the past 20 years that have led to paradigm shifts in the field. Numerous approaches to the teaching of writing have been seen over the years. One of the major concerns voiced by teachers is that the level of writing competency seems to be lower than expected even though students have reached an advanced level in their institutions (Shahrina et al., 2006).

Secondly, the SPM English examination consists of two papers; Paper 1 and Paper 2 where most teachers and even examiners believe that students can score higher grades in their Paper 1 which is essay writing compared to Paper 2 (Sabariah et al., 2008). Therefore, if students can write better in the continuous writing section, then the chances of getting better grades are higher. However, most of the students find essay writing difficult (Gill, The Star, 9 September 2011). Thirdly, although students especially in rural schools have the motivation to write interesting narrative essays, the problem is that most of them do not know how to write narrative essays (Eng, 2006). From the researchers experience as a teacher educator, most students have difficulties when it comes to writing. Students seem unable to construct sentences creatively. Some even refuse to generate ideas or content for their writing (Hoon et al., 2006). Therefore, an approach that could enable the students to improve their narrative writing skills should be used. This study attempts to examine the performance and students' perception in narrative writing. Simultaneously, Task-based learning is utilised to see whether it results in any significant improvement in student narrative writing performance.

\section{Theoretical and Conceptual Framework used in Task-based learning}

According to the research, 'Task-based learning' acts as the input which is also the independent variable while 'Students' Performance in Narrative Writing' is taken as the output; thus it is the dependent variable. As shown in the theoretical and conceptual framework, the process involves two type of lessons; Lesson 1 and Task-based learning Lesson. The theoretical framework represented involves two theories named schemata theory and constructivism theory. 

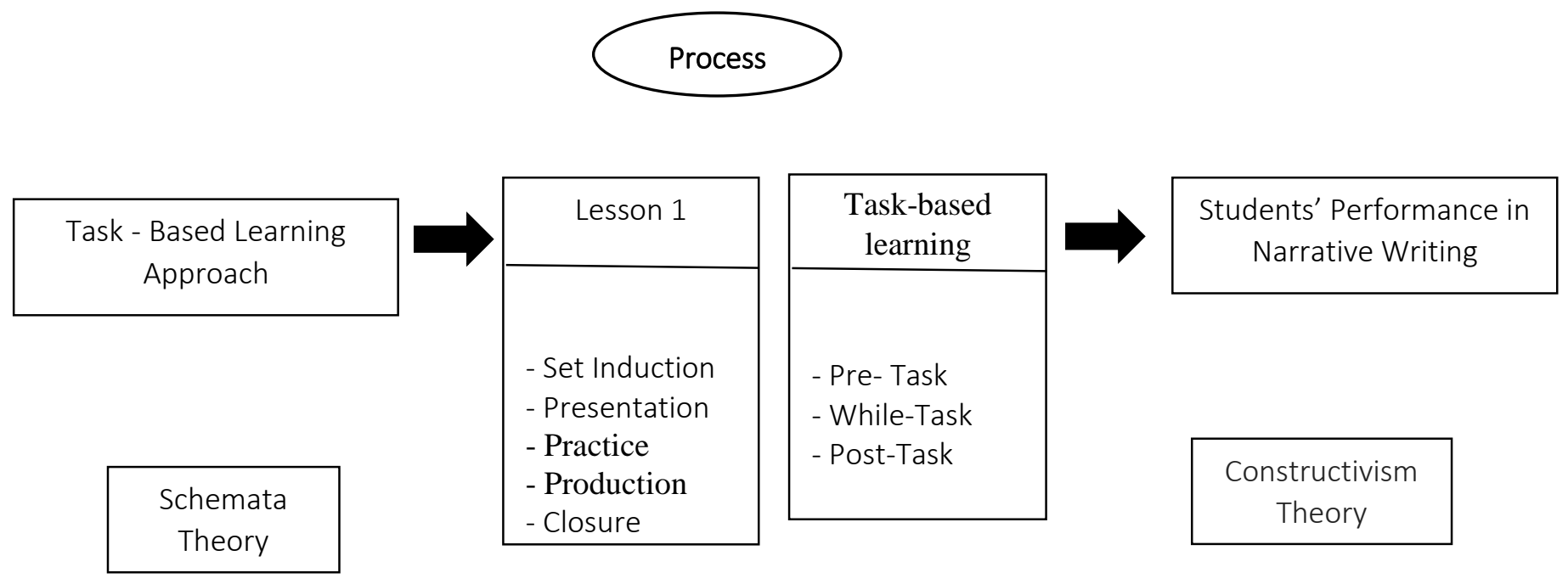

Figure 1. Theoretical framework of the study.

Schemata theory explains how students use prior knowledge to comprehend and learn from text (Rumelhart, 1980). Schemata theory states that the schemata not only affects the way information is interpreted, thus affecting comprehension, but also continues to change as new information is received. Therefore, schemata theory is included in the conceptual framework because during Lesson 1, students are involved in a normal lesson, which activate schemata and allow them to write a composition of about 100 words pertaining to the video clip watched.

Constructivist learning and teaching perspective represents a shift from viewing learners as responding to external stimuli to seeing learners as "active in constructing their own knowledge"; it asserts that "social interactions are important in knowledge construction" (Bruning, Schraw, Norby, \& Ronning, 2004). In addition, constructivism theory prepares students for problem solving. Therefore, students need a significant base of knowledge upon which to interpret and create ideas. Constructivism gives students ownership of what they learn, since learning is based on students' questions and explorations, and often the students have a hand in designing the assessments as well. Constructivist assessment engages the students' initiatives and personal investments in their journals, research reports, and artistic representations. Engaging the creative instincts develops students' abilities to express knowledge through a variety of ways. Therefore, constructivism is included in the conceptual framework during Task-based learning lesson because there are three main phases in a Task-Based lesson; Pre-Task, While-Task and Post-Task. These three stages reflect the chronology of the lesson. Students solve each task in order to construct the final writing.

\section{Methodology}

In the midst of many research designs, the action research design is to be used to frame the study into a certain cycle. The data is collected and analysed in a qualitative paradigm where the data were mainly interpreted and understood in themes and patterns. 


\section{INTERNATIONAL JOURNAL OF ACADEMIC RESEARCH IN PROGRESSIVE EDUCATION AND DEVELOPMENT \\ Vol. 7, No. 2, April 2018, E-ISSN: 2226-6348 @ 2018 HRMARS \\ Participants}

The participants in the study are ten Form Four students from a rural area school. The researchers have chosen Form Four students as the participants particularly because these students have met all the criteria needed as participants for the study.

\section{Instrumentation}

The data collection techniques used in this study were observations, interviews and documents which include students' reflective journal and their written work. For the observations, the protocol and checklist provided a framework for the field notes. Besides that, a modified classroom checklist to assist and facilitate the recordings was also used. To have a continuation in observing the participants' behaviour, the observations were carried out in every session. Such a period had presented a fairly accurate picture of what had occurred in the observed classroom.

Semi-structured interviews were also used to collect the data. To aid the flow of the interviews, an interview protocol was used as a tool to refine the researcher's sensitivity to participants and interviewing techniques. Documents gathered in this study will be reflective journals and participants' written work which is the essay, as the first hand data. The participants used personal reflective journal to reflect their attitudes, their feelings, and their insights about their personal experiences throughout the study. For participants' written work, a suitable topic, appropriate teaching aids for writing activity, the length for the paragraph, the amount of time for completing the paragraph and the marking scheme used to assess the paragraph were discussed with the participants.

\section{Research Procedure}

Data including previous performances in writing skills, especially in narrative writing, were collected from the students. The data were analysed to verify the problem. Three main sources of data which were field notes, monthly test papers and examination papers were used for triangulation in the study. A normal lesson (Lesson 1) was conducted in a normal classroom setting where the students were asked to watch a video clip and write a composition of about 100 words pertaining to the video clip watched. Students' behaviour and reaction were observed and field notes were taken. After the lesson, students' written compositions were collected for analysis and grading. Students' written compositions were analysed based on the adapted marking scheme. The students were asked to write their reflection on their feelings and their perception of the lesson in their reflective journal. Based on the information from the data collected and interpreted in Lesson 1, and the review of current literature, the Task-based learning was implemented that allowed the researchers to make the changes in the learning approach and examine the approach. In this study, only the lesson plan was altered to suit Task- Based Learning design. The other elements of a lesson remained the same as in Lesson 1. It is to determine the action that is responsible for the outcome. When the new approach was being implemented, data were documented and collected on student performance in narrative writing.

\section{Data Analysis}

Descriptive approach was used in analysing the collected data. This included managing the data, reading, describing, classifying and interpreting. First, the data were put in a form to facilitate analysis. Data such as all notes, transcripts, researcher's commentaries, memos and reflections 


\section{INTERNATIONAL JOURNAL OF ACADEMIC RESEARCH IN PROGRESSIVE EDUCATION AND DEVELOPMENT}

Vol. 7, No. 2, April 2018, E-ISSN: 2226-6348 @ 2018 HRMARS

from the observation, interviews and documents were dated, organised, and sequenced. The data were read and memos were written about all field notes, transcripts, and the researcher's commentary to get an initial sense of the data. In addition to recording initial impressions from the data, at this point of analysis, the researcher began searching for recurring themes or common threads. The data were broken down into smaller units, their importance was determined, and the pertinent units were put together in a more general, interpreted form. The concepts in the data were examined and compared to one another and connections were made to form categories. It indeed has provided a basis for structuring analysis and interpretation. The researcher had adopted and adapted Miles and Huberman's (1994) categories to categorise the data. Bogdan and Biklen (1998) also used the same method to categorise data. The categories were the research setting, participants' act, perspectives and ways of thinking, regularly occurring activities, infrequently occurring activities and relationship among participants. In short, the categorisation was identified before, during or after data analysis.

\section{Results and Discussions}

\section{Students' Existing Performance in Narrative Writing}

Students' existing performance in narrative writing was taken from their written composition in the Lesson 1. Lesson 1 was a normal lesson where students watched a video clip and wrote a narrative composition of about 100 words regarding to the clip watched. All the ten students took part in the activity. By the end of the lesson, only nine handed in their work. One student did not want to hand in the work because the student did not write anything on the paper. Students' written narrative compositions were analysed based on the adapted marking scheme. Table 1 shows students' existing performance in narrative writing.

Table 1: Students' Existing Performance in Narrative Writing

\begin{tabular}{|c|c|c|c|c|c|}
\hline \multirow[t]{2}{*}{ Student } & \multicolumn{4}{|c|}{ Assessment Components } & \multirow{2}{*}{$\begin{array}{l}\text { Total } \\
\text { Marks } \\
=40\end{array}$} \\
\hline & $\begin{array}{l}\text { Topic relevance } \\
\text { and sustainably of } \\
\text { interest (10) }\end{array}$ & $\begin{array}{c}\text { Coherence } \\
\text { and cohesion } \\
\text { (10) }\end{array}$ & $\begin{array}{l}\text { Lexical } \\
\text { Resource } \\
(10)\end{array}$ & $\begin{array}{l}\text { Grammatical } \\
\text { Range and } \\
\text { Accuracy (10) }\end{array}$ & \\
\hline 1 & 3 & 3 & 3 & 4 & 13 \\
\hline 2 & 2 & 2 & 2 & 2 & 8 \\
\hline 3 & 5 & 3 & 4 & 4 & 16 \\
\hline 4 & 4 & 3 & 3 & 3 & 13 \\
\hline 5 & 4 & 4 & 4 & 4 & 16 \\
\hline 6 & 5 & 4 & 5 & 4 & 18 \\
\hline 7 & 5 & 4 & 4 & 4 & 16 \\
\hline 8 & 3 & 3 & 5 & 4 & 15 \\
\hline 9 & 3 & 3 & 3 & 3 & 12 \\
\hline 10 & 0 & 0 & 0 & 0 & 0 \\
\hline
\end{tabular}




\section{INTERNATIONAL JOURNAL OF ACADEMIC RESEARCH IN PROGRESSIVE EDUCATION AND}

DEVELOPMENT

Vol. 7, No. 2, April 2018, E-ISSN: 2226-6348 @ 2018 HRMARS

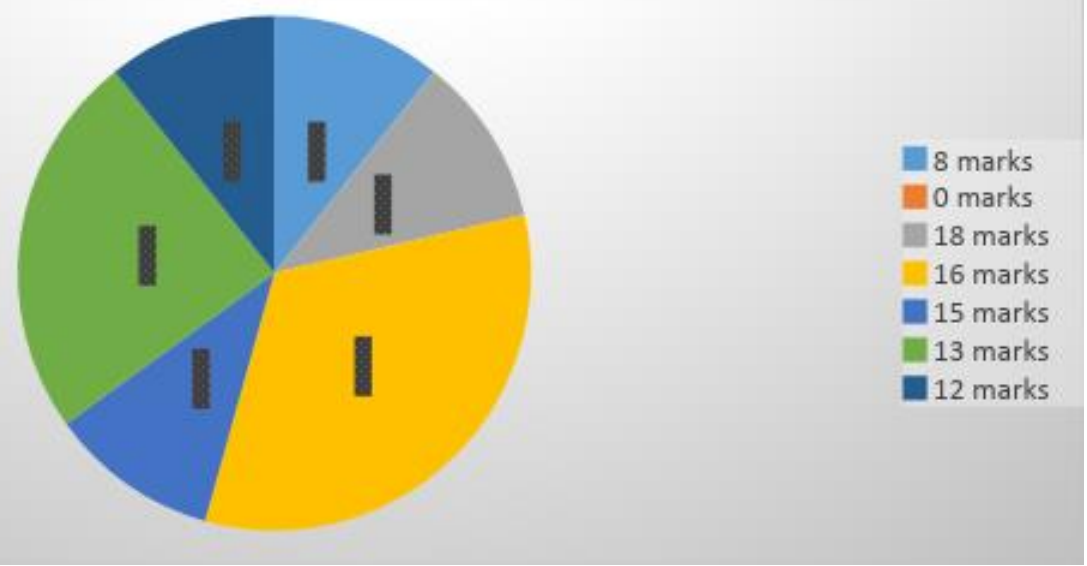

Figure 2. Percentage of students' existing performance in narrative writing according to marks.

Figure 2 showed that the number of students who scored 18 out of 40 marks were one which is $11 \%$, three students scored 16 out of 40 marks which is $34 \%$, one student scored 15 out of 40 marks which is $11 \%$, two students scored 13 out of 40 marks which is $25 \%$, one student scored 12 out of 40 marks which is 11\%, one student scored 8 out of 40 marks which is $11 \%$ and one student did not attempt to write.

\section{Students' Performance in Narrative Writing Through Task-based learning}

Students' performance in narrative writing was taken after implementation of the Task-based learning lesson. The lesson was conducted by making task completion as the lesson outcome. Students' written narrative composition were collected to analyse and marks awarded using the adapted marking scheme. During the activity, the students were observed and field notes were taken using the observational protocol form. All ten students took part in all the activities carried out in the lesson.

\begin{tabular}{|c|c|c|c|c|c|}
\hline \multirow[b]{2}{*}{ Student } & \multicolumn{4}{|c|}{ Assessment Components } & \multirow{2}{*}{$\begin{array}{l}\text { Total } \\
\text { Marks } \\
=40\end{array}$} \\
\hline & $\begin{array}{l}\text { Topic relevance } \\
\text { and sustainably } \\
\text { of interest (10) }\end{array}$ & $\begin{array}{l}\text { Coherence and } \\
\text { cohesion (10) }\end{array}$ & $\begin{array}{c}\text { Lexical } \\
\text { Resource (10) }\end{array}$ & $\begin{array}{l}\text { Grammatical } \\
\text { Range and } \\
\text { Accuracy (10) }\end{array}$ & \\
\hline 1 & 8 & 8 & 8 & 7 & 31 \\
\hline 2 & 6 & 6 & 6 & 5 & 23 \\
\hline 3 & 5 & 6 & 6 & 5 & 22 \\
\hline 4 & 6 & 6 & 7 & 4 & 23 \\
\hline 5 & 8 & 8 & 8 & 6 & 30 \\
\hline 6 & 7 & 7 & 7 & 7 & 28 \\
\hline 7 & 8 & 8 & 8 & 7 & 31 \\
\hline 8 & 9 & 9 & 8 & 7 & 33 \\
\hline 9 & 6 & 6 & 5 & 6 & 23 \\
\hline 10 & 8 & 7 & 8 & 7 & 30 \\
\hline
\end{tabular}




\section{INTERNATIONAL JOURNAL OF ACADEMIC RESEARCH IN PROGRESSIVE EDUCATION AND DEVELOPMENT}

Vol. 7, No. 2, April 2018, E-ISSN: 2226-6348 @ 2018 HRMARS

Figure 3. Percentage of students' Task-based learning performance in narrative composition according to marks obtained.

The findings from the narrative writing composition showed a tremendous improvement in students' performance in narrative composition. All of the students scored more than 20 marks out of 40 marks for their composition ( $50 \%$ and above). The findings from the lesson using task as the central of the lesson was encouraging compared to the findings in the Lesson 1.

Table 3 Difference between marks obtained by students for lesson 1 and Task-based learning lesson.

\begin{tabular}{|c|c|c|c|}
\hline \multirow{2}{*}{ Students } & \multicolumn{3}{|c|}{ Marks Obtained } \\
\cline { 2 - 4 } & Lesson 1 & $\begin{array}{c}\text { Task-based learning } \\
\text { Lesson }\end{array}$ & Difference \\
\hline 1 & 13 & 31 & +18 \\
\hline 2 & 8 & 23 & +15 \\
\hline 3 & 16 & 22 & +6 \\
\hline 4 & 13 & 23 & +10 \\
\hline 5 & 16 & 30 & +14 \\
\hline 6 & 18 & 28 & +10 \\
\hline 7 & 16 & 31 & +15 \\
\hline 8 & 15 & 33 & +18 \\
\hline 9 & 12 & 23 & +11 \\
\hline 10 & 0 & 30 & +30 \\
\hline
\end{tabular}

\section{Students' perceptions of Task-based learning in narrative writing before introduction of Task-} based learning

Students' perceptions and opinion about narrative writing through Task-based learning were gathered from their written reflective journal, observation checklist, field notes and interviews. The findings in the observation revealed that most of them had a difficult time in writing the composition. Based on students' reflective journals, most of the students have negative impression of the lesson. Many admitted feeling nervous when asked to write the narrative composition.

Some examples from the reflective journals are:

Student 6 : "When I writing the composition just now, we felt scared. Because I don't like my composition wrong. Selain itu (besides that), I felt angry and tension because, I don't know how to start to writing."

Student 8 : "During the activity I have just little bit difficulties. Terutama (specially) time I want to write the composition. My problems is have some words yang I don't know in English."

Student 6 : "When I writing the composition just now, many problems I have. The problem such as I don't know how to change my words into English language because I started to writing my composition in Malay language. So for change into English language it is very difficulties for me." 


\section{INTERNATIONAL JOURNAL OF ACADEMIC RESEARCH IN PROGRESSIVE EDUCATION AND DEVELOPMENT}

Vol. 7, No. 2, April 2018, E-ISSN: 2226-6348 @ 2018 HRMARS

After introduction of Task-based learning

Students' reflective journals, observation checklist and interview transcription were read, described and classified for better comprehension of students' perceptions about Task-based learning Lesson. Students' attitudes, feelings, thoughts and insights about personal experiences and reflection were synthesised based on the activities conducted during the lesson. During the writing of the narrative composition stage, most of them felt that it was easy to write narrative composition when the keywords and the sentence structure were given as guidance.

Some excerpts from the reflective journal exemplify this view.

Student 1 : "it was too easy to write the composition because I had too much idea for my writing. The time that given to write composition give me challenging because I feel the time is short and I will not done my composition. The key word that was given was help me to write a composition."

Student 6 : "Give idea, challenging, easy, enjoy, interesting, easy because teacher given key words, yakin diri (confidence)"

Student $7 \quad$ : "write the composition is very challenging because im not have a guidance. I feel easy to write the composition when the teacher give the key word and how to make the sentences"

\section{Observation Checklist}

The observation checklist was also examined to obtain students' perception in narrative writing through Task-based learning. The findings from the observation checklist were described and classified to illustrate students' perception on each stage in the Task-based learning lesson. During the Pre-Task stage, the students always listened carefully to the teacher's instruction. Students always showed their interest and this could be seen from their facial expression. During the While-Task stage where the sentence structures were introduced, most of the students felt motivated and always paid full attention to the teacher's explanation. During the Post-Task stage, the students felt happy when the teacher gave them time to make the amendments. Students felt that they could correct as much as possible the mistakes in their composition. Some student especially the boys felt confident when the teacher called them randomly to present their work.

\section{Students' Interview}

The findings showed that most of the students did not have negative perception on either writing skills or narrative writing skill. What bothered them was the approach in learning the narrative writing skill. Many students found that the activities in Lesson 1 were confusing and it was difficult for them to write the composition. Some examples of transcription of the interview session:

Teacher : Okay... okay... okay... now how do you feel about the first lesson?

Student 4 : Confused... stressed

Teacher : You feel confused... Stressed...

Student 2 : Nervous...

Teacher : You feel nervous.. what else..how do you feel in the first lesson compared to the second lesson?

Student 5 : Enjoy in the second lesson. First lesson no idea 
INTERNATIONAL JOURNAL OF ACADEMIC RESEARCH IN PROGRESSIVE EDUCATION AND

DEVELOPMENT

Vol. 7, No. 2, April 2018, E-ISSN: 2226-6348 @ 2018 HRMARS

Teacher : You enjoyed in the second lesson and you did not enjoy in the first lesson? Any other responses?

Student 2 : Cannot understand of the...

In contrast, many students felt that the second or Task-based learning lesson was interesting and they could learn in a fun and enjoyable way.

Some examples of transcription of the interview session.

Student $4 \quad$ : I think the second lesson, when I write the story, it is so easy for me... write the story...

Teacher : Okay... you feel that it is much easier to write the narrative writing in the second lesson?

Student $4 \quad$ :Yes...

Most of the students preferred to write narrative composition when it is in a form of a task. Students claimed that it is easier for them to get the ideas and the activity is challenging. They also agreed that there is a desire to compete with peers to complete the task. Students' perspectives on every stage in Task-based learning based on the interview were analysed in a form of a table.

\begin{tabular}{|c|c|c|}
\hline Stages & Activity & Perspectives \\
\hline \multirow[t]{3}{*}{ Pre-Task } & Watching video clip & $\begin{array}{l}\text { Enjoying } \\
\text { Interesting } \\
\text { Could get ideas on what to write }\end{array}$ \\
\hline & $\begin{array}{r}\text { Completing worksheet - } \\
\text { vocabulary } \\
\text {, phrases }\end{array}$ & $\begin{array}{c}\text { Keywords were very useful and made the writing } \\
\text { easier }\end{array}$ \\
\hline & $\begin{array}{c}\text { Introduction to sentence } \\
\text { structure }\end{array}$ & $\begin{array}{c}\text { Sentence structure was helpful and created } \\
\text { confidence in writing }\end{array}$ \\
\hline While-Task & Writing the composition & $\begin{array}{l}\text { - Could write better and learn new words and } \\
\text { structures } \\
\text { - Had the urge to complete the task within } \\
\text { the time } \\
\text { - Had the competitive attitude among peers } \\
\text { - } \text { Able to utilise the language to its maximum }\end{array}$ \\
\hline Post-Task & Presentation & $\begin{array}{l}\text { - } \text { Can share ideas and work with peers } \\
\text { - Shy- what others would think if the work is } \\
\text { no good } \\
\text { - Embarrassed - students may laugh if wrong } \\
\text { - Can learn from others-Build confidence }\end{array}$ \\
\hline
\end{tabular}


Vol. 7, No. 2, April 2018, E-ISSN: 2226-6348 @ 2018 HRMARS

\begin{tabular}{|l|l|l|}
\hline & Correction teacher & $\begin{array}{r}- \text { Likes when teacher corrects the mistakes } \\
\text { - Can correct own mistakes } \\
\end{array}$ \\
& $\begin{array}{r}- \text { Can learn new things and improve language } \\
\text { ability/ writing skill }\end{array}$ \\
\cline { 2 - 3 } & Final amendments & Can correct the mistakes and edit the composition \\
\hline
\end{tabular}

\section{Conclusion}

Students' overall performance in Lesson 1 and in Task-based learning lesson is analysed and compared to identify the differences. Student performance in narrative writing through Taskbased learning showed improvement. Most of the students were able to score from 10 to 19 marks out of 25 marks which categorized them into grade ' $D$ ', ' $C$ ' and ' $B$ '. Most of the students claimed that the worksheet on vocabularies and phrases, and the recollection of sentence structures enabled them to perform well in the composition. All of the students stated that they felt confident and happy to complete the narrative composition. They felt confident because of the vocabulary and the sentence structures and the nature of the lesson.

Besides that, students perceived Task-based learning as an approach that could help them in narrative writing skill. The activities carried out in all the stages in the Task-based learning lesson seemed useful and fostered the learning process. Interesting and knowledgeable input in the PreTask stage aided the students in the While-Task stage which was the core of the Task-based learning. The completion of the task created a competitive environment among the students to utilise the knowledge that they have and integrate the new knowledge in their performance. The urge to complete the task within the time forced them to perform better in their narrative composition.

The findings of the study revealed that the Task-based learning helped Form Four students to recognize their strengths and weaknesses in writing narrative essays. This study helped to create an awareness among teachers to understand the students' perception toward narrative writing skills. Indirectly, it is believed to aid the teachers to adapt their teaching method appropriately for the students in order to prepare them for the "Sijil Pelajaran Malaysia" (SPM) examination.

\section{References}

Bogdan, R. C., \& Biklen, S.K. (1998). Qualitative research in education: An introduction to theory and methods (3rd ed.). Needham Heights, MA: Allyn \&

Bacon.Bruning, R., Schraw, G., Norby, M., \& Ronning, R. (2004). Cognitive psychology and Instruction. Upper Saddle River, NJ: Prentice Hall.

Eng, T. K. (2006). Writing English essay within dominant discourses in Malaysian schools. Jurnal Pendidik dan Pendidikan, 21, 23-45.

Gill, J. K. (2011, September 7). Narrative Essay. The Star. Retrieved from http://thestar.com.my/education/story.asp?file=/2008/9/7/education/1936035\&sec=ed ucation

Hoon, T. B., Emerson, L., \& White, C. (2006). Reforming ESL Writing Instruction in Tertiary Education: The Writing Centre Approach. The English Teacher, 35, 1- 14. 


\section{INTERNATIONAL JOURNAL OF ACADEMIC RESEARCH IN PROGRESSIVE EDUCATION AND DEVELOPMENT}

Vol. 7, No. 2, April 2018, E-ISSN: 2226-6348 @ 2018 HRMARS

Miles, M. B., \& Huberman, A. M. (1994). Qualitative data analysis: An expanded source book. Thousand Oaks, CA: Sage.

Rumelhart, D. E. (1980). Toward an interactive model of reading. In S. Dornic (Ed.), Attention and performance IV. New York, NY: Academic Press. Sabariah Md. Rashid, \& Chan Swee Heng. (2008) Exploring the Interplay of Mode of Discourse and Proficiency Level in ESL Writing Performance. Malaysia: The English Teacher, 37, 105- 122.

Shahrina Md. Nordin, \& Norhisham bt Mohammad. (2006). The best of two approaches: Process/ Genre Based Approach to teaching. The English Teacher, 35, 75-85.

Stringer, E. T. (1999). Action research. Thousand Oaks, CA: Sage.

Wreikat, Y. A., Kabilan, M. K., \& Abdullah, A. C. (2014). The Rural Learning Environment and Pupils' Learning of the English Language. Pertanika Journal of Social Sciences and Humanities, 22(1), 35 - 56. 